\title{
Prevalent HBeAg-negative HBV DNA-positive Chronic Hepatitis B Individuals in Bangladesh
}

\author{
SM Rashed UI Islam ${ }^{1}$, , Umme Shahera², Munira Jahan ${ }^{3}$, Shahina Tabassum ${ }^{4}$ \\ Keywords: HBeAg-negative Chronic Hepatitis B patients, Hepatitis B virus DNA, Hepatitis B virus vaccination. \\ Euroasian Journal of Hepato-Gastroenterology (2021): 10.5005/jp-journals-10018-1339
}

A laboratory-based analysis of hepatitis B surface antigen (HBsAg)-positive patients were accomplished to retrieve insights association of hepatitis $B$ virus (HBV) DNA and hepatitis $B$ e antigen $(\mathrm{HBeAg})$ in Bangladesh as several kinds of literature have reported an abundance of $\mathrm{HBeAg}$-negative chronic hepatitis $\mathrm{B}$ (CHB) patients in Southeast Asia. ${ }^{1,2}$ A total of 25,996 patients expressing HBsAg attending the Department of Virology, Bangabandhu Sheikh Mujib Medical University, Dhaka, Bangladesh, between January 2014 and December 2015 were enrolled for the study. HBV DNA was analyzed by Applied Biosystems 7500 Real-time PCR system as per the manufacturer's protocol (Robo Gene HBV DNA Quantification Kit, Roboscreen GmbH, Leipzig, Germany), and the levels of serum HBV DNA were expressed as IU/mL. Detection of $\mathrm{HBeAg}$ was performed by enzyme immunoassay (Enzo Life Sciences, Inc, Farmingdale, New York, USA). The mean age of the study population was $32.43 \pm 11.96$ years (range $2-98$ years). Among the study population, 20,435 (78.6\%) were males and 5,561 (21.4\%) were females. The levels of HBV DNA were $>100 \mathrm{lU} /$ $\mathrm{mL}$ in 11,270 patients (43.4\%), whereas HBV DNA were below $<100$ $\mathrm{IU} / \mathrm{mL}$ in 14,726 patients (56.6\%). Out of total 25,996 patients, HBeAg was positive in 3,388 (13\%) patients. Thus, the majority of the patients $(N=22,608)$ were HBeAg-negative. Table 1 have shown the patient's profile and status of HBV DNA and HBeAg in these patients. Among HBeAg-negative patients, 12\% patients had HBV DNA $>20,000 \mathrm{IU} / \mathrm{mL}$.

The study also checked the age distribution and HBV DNA according to the HBeAg serostatus. The highest prevalence of HBV DNA was observed in the 21 to 30 age-group (41.6\%). Among the study population, 0.7 and $11.8 \%$ belonged to $<10$ - and 10 to 20 -year age-groups, respectively. The association among these variables has been shown in Figure 1.

Univariate logistic regression approach according to $\mathrm{HBeAg}$ serostatus and age revealed that among the $\mathrm{CHB}$ patients aged $<40$ years, there were significant (odds ratio $=1.61, p<0.0001$ ) number of $\mathrm{HBeAg}$-positive cases in comparison to $\mathrm{HBeAg}$-negative $\mathrm{CHB}$ cases. The comparison of different HBV DNA levels with $\mathrm{HBeAg}$ status showed that the high HBV DNA content of $>20,000 \mathrm{lU} / \mathrm{mL}$ was observed more frequently in $\mathrm{HBeAg}$-positive patients compared to the HBeAg-negative CHB patients (odds ratio $=17.53, p<0.0001$ ) considering HBV DNA $<2,000 \mathrm{IU} / \mathrm{mL}$ as reference. The details of the regression analysis are plotted in Table 2.

The study presented here has shown that a vast majority of patients with $\mathrm{CHB}$ in Bangladesh belong to the $\mathrm{HBeAg}$-negative group. This is in agreement with the data shown by other studies
${ }^{1-4}$ Department of Virology, Bangabandhu Sheikh Mujib Medical
University, Dhaka, Bangladesh Address reprint requests to: SM Rashed UI Islam, Department of Virology, Bangabandhu Sheikh Mujib Medical University, Dhaka, Bangladesh, Phone: + 8801713236399, e-mail: smrashed@bsmmu. edu.bd

How to cite this article: Rashed UI Islam SM, Shahera U, Jahan M, et al. Prevalent HBeAg-negative HBV DNA-positive Chronic Hepatitis B Individuals in Bangladesh. Euroasian J Hepato-Gastroenterol 2021;11(1):49-50.

Source of support: Nil

Conflict of interest: None

regarding the prevalence of $\mathrm{HBeAg}$-negative $\mathrm{HBV}$ DNA-positive patients in this subcontinent as well as some European countries. ${ }^{1-4}$ Several HBeAg-negative patients also develop complications of liver diseases in the Asian country that exhibit some contrast with Western countries. ${ }^{5}$

Another notable observation is related to the finding that about $12.5 \%$ study population of $<20$ years of age was suffering from $\mathrm{CHB}$ infection. $\mathrm{HBV}$ is a preventable disease and vaccination coverage has reached $98 \%$ or more. This has drastically reduced HBV prevalence among children of age 5 or more. But, a huge adolescent population of less than 20 years has been harboring the virus. Thus, elimination of HBV by 2030 would have to take into account this group in addition to EPI-based vaccination and birth-dose vaccination. ${ }^{6}$

The study is endowed with several notable limitations as the clinical statuses of the patients are unknown. But, this study mainly aimed to assess the association between relations of HBV DNA vs HBeAg status. The outcome of this study would be meaningful to address other HBV-related problems in the context of Bangladesh and other developing countries with similar socioeconomic conditions.

\section{ACKnOWledgments}

The authors express their gratitude to Amirul Huda Bhuyian during the data entry for analysis and Umme Kulsum for her expert technical support.

\section{OrCID}

SM Rashed UI Islam @i https://orcid.org/0000-0002-8164-5905

(o) The Author(s). 2021 Open Access This article is distributed under the terms of the Creative Commons Attribution 4.0International License (https://creativecommons. org/licenses/by-nc/4.0/), which permits unrestricted use, distribution, and non-commercial reproduction in any medium, provided you give appropriate credit to the original author(s) and the source, provide a link to the Creative Commons license, and indicate if changes were made. The Creative Commons Public Domain Dedication waiver (http://creativecommons.org/publicdomain/zero/1.0/) applies to the data made available in this article, unless otherwise stated. 
Prevalent HBeAg-negative HBV DNA-positive Chronic Hepatitis B Individuals

Table 1: Demography and distribution of study parameters according to HBeAg serostatus

\begin{tabular}{|c|c|c|c|c|c|}
\hline Subjects & & $\begin{array}{l}\text { Total } \\
n(\%)\end{array}$ & $\begin{array}{l}\text { HBeAg positive } \\
n(\%)\end{array}$ & $\begin{array}{l}\text { HBeAg negative } \\
n(\%)\end{array}$ & $p$ value \\
\hline Total study population & & $25,996(100)$ & $3,388(13)$ & $22,608(87)$ & - \\
\hline \multirow{2}{*}{ Gender } & Male & $20,435(78.6)$ & $2,663(78.6)$ & $17,772(78.6)$ & \multirow{2}{*}{$>0.05$} \\
\hline & Female & $5,561(21.4)$ & $725(21.4)$ & 4,836 (21.4) & \\
\hline Mean age (years) & Mean \pm SD & $32.43 \pm 11.96$ & $28.41 \pm 12.78$ & $1.21 \pm 0.41$ & $<0.0001$ \\
\hline Age range (years) & & $2-98$ & $2-90$ & $2-98$ & - \\
\hline HBV DNA levels ( $\log _{10} \mathrm{IU} / \mathrm{mL}$ ) & Mean \pm SD & $4.33 \pm 1.96$ & $6.12 \pm 1.88$ & $3.77 \pm 1.61$ & $<0.0001$ \\
\hline \multirow{4}{*}{ HBV DNA levels (IU/mL) category } & $<100$ & $14,726(56.6)$ & $565(16.7)$ & $14,161(62.6)$ & \multirow{4}{*}{$<0.0001$} \\
\hline & $100-2,000$ & $4,304(16.6)$ & $304(9)$ & $4,000(17.7)$ & \\
\hline & $2,001-20,000$ & $1,957(7.5)$ & $234(6.9)$ & $1,723(7.6)$ & \\
\hline & $>20,000$ & $5,009(19.3)$ & $2,285(67.4)$ & $2,724(12)$ & \\
\hline
\end{tabular}

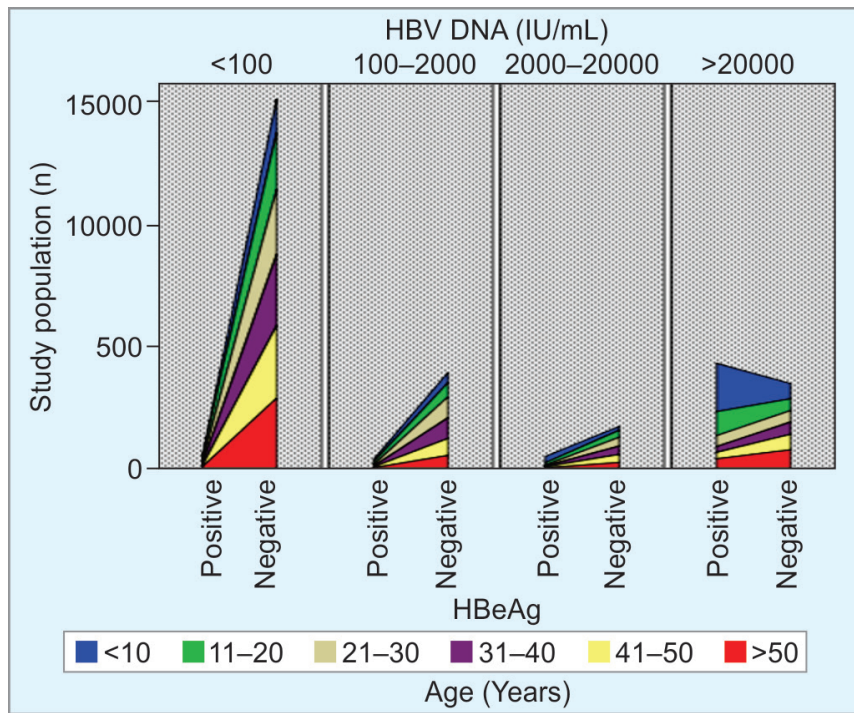

Fig.1: Diagrammatic age distribution and HBV DNA according to the HBeAg status

Table 2: Regression analysis of age and HBV DNA according to HBeAg serostatus on $\mathrm{CHB}$ patients

\begin{tabular}{|c|c|c|c|c|c|c|}
\hline Subjects & & $\begin{array}{l}\text { Total population } \\
n(\%)\end{array}$ & $\begin{array}{l}\text { HBeAg positive } \\
n(\%)\end{array}$ & $\begin{array}{l}\text { HBeAg negative } \\
n(\%)\end{array}$ & OR $(95 \% \mathrm{Cl})$ & $p$ value \\
\hline \multirow{3}{*}{ Age category } & $>40$ & $5,433(20.9)$ & $501(14.8)$ & $4,932(21.8)$ & Reference & - \\
\hline & $<40$ & $20,563(79.1)$ & $2,887(85.2)$ & $17,676(78.2)$ & $1.61(1.46-1.78)$ & $<0.0001$ \\
\hline & $<2,000$ & $19,030(73.2)$ & 869 (25.6) & $18,161(80.3)$ & Reference & - \\
\hline \multirow[t]{2}{*}{ HBV DNA levels (IU/mL) } & $2,000-20,000$ & $1,957(7.5)$ & $234(6.9)$ & $1,723(7.6)$ & $2.84(2.44-3.31)$ & $<0.0001$ \\
\hline & $>20,000$ & $5,009(19.3)$ & $2,285(67.4)$ & $2,724(12)$ & $17.53(16.06-19.14)$ & $<0.0001$ \\
\hline
\end{tabular}

${ }^{*} n=$ frequency, $\%=$ percentages

\section{References}

1. Kumar M, Sarin SK, Hissar S, et al. Virologic and histologic features of chronic hepatitis B virus-infected asymptomatic patients with persistently normal ALT. Gastroenterology 2008;134(5):1376-1384. DOI: 10.1053/j.gastro.2008.02.075.

2. Al-Mahtab M, Akbar SM, Rahman S, et al. Biochemical, virological, immunological and histopathological features of 702 incidentally detected chronic hepatitis B virus carriers in Bangladesh. Digestion 2012;86(1):1-5. DOI: 10.1159/000337529.

3. Fouad R, Musa S, Sabry D, et al. Analysis of clinical and virologic features in Hepatitis Be Antigen ( $\mathrm{HbeAg}$ )-negative and $\mathrm{HbeAg}$-positive Egyptian chronic hepatitis B patients. Afr Health Sci 2020;20(2):649-655. DOI: 10.4314/ahs.v20i2.13.
4. Zarski J-P, Marcellin P, Leroy V, et al. Characteristics of patients with chronic hepatitis $B$ in France: predominant frequency of $\mathrm{HBe}$ antigen negative cases. J Hepatol 2006;45(3):355-360. DOI: 10.1016/ j.jhep.2006.03.007.

5. Al-Mahtab M, Rahman S, Akbar SM, et al. Clinical use of liver biopsy for the diagnosis and management of inactive and asymptomatic hepatitis B virus carriers in Bangladesh. J Med Virol 2010;82(8): 1350-1354. DOI: 10.1002/jmv.21830.

6. Akbar SMF, Al Mahtab M, Begum F, et al. Implications of Birth-Dose Vaccination against Hepatitis B Virus in Southeast Asia. Vaccines (Basel) 2021;9(4):374. DOI: 10.3390/vaccines9040374. 